\title{
The Use of Instagrams as A Digital Communication Media by Holyspicy in The Covid-19 Pandemic
}

\author{
Ririn Puspita Tutiasri \\ Universitas Pembangunan Nasional "Veteran" Jawa Timur \\ e-mail: ririn_puspita.ilkom@upnjatim.ac.id \\ Eunike Jayanti Widiastuti \\ Universitas Pembangunan Nasional "Veteran" Jawa Timur \\ e-mail: 18043010051@student.upnjatim.ac.id \\ Sesilia Tri Ria Murti \\ Universitas Pembangunan Nasional "Veteran" Jawa Timur \\ e-mail: 18043010052@student.upnjatim.ac.id \\ Inggrid Priscillia \\ Universitas Pembangunan Nasional "Veteran" Jawa Timur \\ e-mail: 18043010054@student.upnjatim.ac.id
}

\begin{abstract}
The growing business market in Indonesia, especially in the culinary sector, is currently getting benefits from the presence of social media. Social media is now an unforgettable tool for almost all entrepreneurs, especially for entrepreneurs in the culinary field to promote their products in the midst of the Covid-19 pandemic. Instagram provides various facilities for its users, especially in this case users who use Instagram to carry out product and brand promotion activities. Fast food is one of the culinary businesses that are currently booming, and Holyspicy is one of the culinary producers that uses Instagram as a medium of communication for promotion. This research focuses on how Instagram as a social media is used by Holyspicy as a main marketing and promotion tool. The research method used in this research is descriptive qualitative method. The theory used in this research is new media theory. Based on the results of the research, Instagram played an important role in Holyspicy's culinary business as a marketing and sales communication medium during the Covid-19 pandemic, as evidenced by the fact that during the Covid-19 pandemic, the income obtained by Holyspicy remained stable and actually experienced a significant increase at the beginning of the Covid-19 pandemic. Management of Instagram features such as hashtags, photo uploads, photo titles, and replying to customer comments also affects consumer buying interest.
\end{abstract}

Keywords: Social Media, Instagram, Marketing Communication, Promotion, Culinary Business

\section{INTRODUCTION}

The development of information and communication technology has brought many changes to people's lives. The emergence of smartphones and the internet has made it easier for various kinds of community activities. Almost everyone has a smartphone that can connect to the internet network. This also makes every human action and activity whenever and wherever it is inseparable from the internet, especially social media, including Indonesian society.

According to Bianda Ludwianto (2020) in kumparan.com, the results of research from Global Digital Reports 2020 where the data show that internet users in Indonesia are quite high, with an average of 7 hours 59 minutes per day in 2019. The research also 
shows that $64 \%$ Indonesian people with the internet or that is, with a total of 175.4 million internet users. The internet itself consists of various forms but the most popular and often used are social media such as Instagram, Facebook, and Youtube. The reasons for its use also vary from looking for information, as a medium of entertainment, to what is currently being done is marketing and selling a product. However, in the midst of the Covid-19 pandemic like today the economy in Indonesia is weakening.

Furthermore, the government continues to promote keeping safe distance activities in various public places. It has resulted in many business activities that have to close temporarily and even stop all operational activities, resulting in the dismissal of employees. Starting from this condition, there have been many online merchants or entrepreneurs who market their products or services through social media, especially Instagram. This has resulted in a change in the pattern of using Instagram in the community, where at first it was only used for personal gain, now it has become a means of business by sharing photos of products or services.

Related to the case, the entrepreneurs must be creative and implement their own marketing strategies so their businesses running well, one of them is by using social media. Through marketing communication, businessman can introduce and provide knowledge to consumers and the public regarding the products or services offered by the company, what benefits will be obtained from these products or services, and how to enable consumers to own or enjoy these products or services. Even through good marketing communication, a company will get more attention to its brand image in the community (brand awareness) and more consumers will consume or enjoy the products or services offered. Reza (2016: 66) states that marketing communication is the communication of a company that is related to planning, using, implementing, and evaluating its marketing communication strategy.

The existence of social media becomes a breath of fresh air for entrepreneurs in the midst of this pandemic. Maribeth (2019) states that social media can also have an influence on its users by changing social life in society either positively or negatively. One of them is by being used as a medium for doing business. This is because the use of social media is quite easy, costs less, and can determine the target market to be targeted through existing features. In Indonesia, there are many food businesses such as spicy food that offer their products through social media, one of which is Holyspicy. Holyspicy itself is a local Surabaya food business that was founded in 2017 and provides a wide variety of spicy food menus at relatively affordable prices.

Starting from his hobby of surfing on Instagram, Tiara Puspitasari decided to open a spicy food business and market it through Instagram. Holyspicy markets its products through Instagram and is actively promoting so that it also gets a positive response from the public. This is evident from the number of followers who have reached 33,600 accounts to date. Holyspicy uses Instagram to introduce, market and attract consumers.

In the midst of difficult economic conditions due to the impact of Covid-19, Holyspicy experienced a decline in sales but has been able to survive until now while still prioritizing quality and health protocols in its production process. Holyspicy has succeeded in attracting public interest and increasing sales through uploading product photos, testimonials from customers, and videos in the midst of difficult economic conditions due to the impact of Covid-19. Based on these reasons, the purpose of this study is to find out about the use of Instagram as a media of communication in the midst of the Covid-19 pandemic. Based on this background, the focus of this research is how 
Instagram as a social media is used by Holyspicy as a means of marketing and main promotion which is carried out using a qualitative descriptive method.

\section{Theoretical Review}

\section{Marketing Communication}

Communication is the foundation of marketing. Marketing can be successful when combined with more effective communication. Kotler and Keller (2007: 6) say that marketing is a social process where individuals and groups get what they need by creating, offering and exchanging valuable products. It means that marketing covers a comprehensive system of business planning, product promotion, and pricing. Communication has a close relationship with marketing. In marketing, communication activities are complex, unlike talking with family or friends. Good communication can provide the right message to the communicant, through the right communication strategy and a fairly mature planning process.

Kotler and Keller (2012: 498) say that marketing communication is a means that can be used by a company to inform and persuade consumers, either directly or indirectly, about the products to be marketed. Marketing communication is a form of communication that aims to strengthen marketing strategies so as to reach a wider market segment. Companies will use various forms of marketing communication as a means of promotion about the products they will offer in order to achieve financial goals.

\section{Online Marketing Communication}

In the globalization era, the internet provides space to make direct sales to consumers in industrial markets. The sale of goods and services directly through the internet is called e-commerce. Currently, there are many companies that offer products and services via the internet or social media. There are several reasons why a company runs a business using e-commerce facilities (Morissan, 2010: 335 - 337), namely that it can reach audiences around the world, can carry out interactive communication in an efficient manner, can reach target consumers, it is easier to communicate changes. information such as price changes and other information, improving the quality of service to customers because it is available 24 hours, seven days a week, getting immediate feedback from consumers, is an alternative distribution channel, providing cost effective and efficient dissemination of information.

\section{Marketing Communication Strategy}

Strategy is planning and management to achieve a desired goal. To achieve this goal, strategy does not have a function as a road map that only shows the direction, but must show the part of its operational tactics (Effendy, 2002: 29). Communication strategy is a guide from communication planning with communication management to achieve predetermined goals. Strategic planning according to Kotler (2001: 241) is a managerial process for developing and maintaining a strategic direction and aligning objectives as marketing opportunities.

The communication strategy is a pattern that is used to achieve predetermined and formulated goals as best as possible by paying attention to external and internal forces so that it is clear what program will be carried out. Communication strategy is also a plan to achieve a goal to achieve marketing opportunities. 


\section{New Media}

Creeber and Martin (2009) define new media as a product of technology-mediated communication with digital computers. The new media theory is a theory developed by Pierre Levy. There are two views put forward by Pierre Levy in the theory of new media. The first is the view of social interaction, this is what distinguishes the media according to their closeness to face-to-face interactions. Second, the view of social integration which is a picture of the media not in the form of information, interaction or dissemination, but in the form of rituals or how humans use media as a way of creating society. Media is not only an instrument of information and a way to achieve selfinterest, but unites us into several forms of society that give us a sense of belonging. The world of media and communication is starting to look different with the arrival of new media that is not limited to a particular sector.

LittleJohn (2009: 413-414) states, new media leads to the view that there are differences between the previous media era and the current media. New media theory provides two dominant views on the differences between social interaction approaches and social integration. The social interaction approach looks at how close the media is to the audience in the face-to-face interaction model. Broadcast-oriented forms of media emphasize the transmission of information, thereby reducing the possibility of interaction. The difference with social integration is that social integration describes the media not included in the form of information, interaction and dissemination of information but how humans use media as a way to create a new society. Face-to-face interaction is no longer the main standard for comparison of communication media.

New media is the result of technology-mediated communication. There are differences between the new views in the previous media era and the current media era. New media is often referred to as converged media. In the theory of new media, media is not only described as a way to achieve self-interest but the media also unites each individual into several forms of groups that can give each other a sense of belonging. New media is described as a digital media that has solid, interactive and impartial characteristics.

\section{Social media}

The media plays an important role in conveying a communication message. In communication process, the media becomes a means of sending messages to message recipients. Social media provides a two-way, more individual form of communication. Marketers can get information about their consumer habits through social media and can make personal interactions to build deeper bonds. Michael Haenlein and Andreas Kaplan said that social media is a group that is built on the basis of internet-based ideology and technology.

Williams et al (2012) say that social media allows its users to be able to communicate with millions of other users. This is a great opportunity for marketers that can be used as a marketing communication tool. Social media makes it possible to share information between younger users (Akrimi and Khemakem, 2012).

\section{Social Media Marketing}

Drury (in Veby Zifania, 2014: 17) says that the use of social media has started to be used frequently in marketing. In business, social media is a means of supporting communication in marketing quickly and more profitably than selling offline. Social media is a great opportunity that can be used by business people in developing a 
business. The integration of social media and marketing is an effort to support marketing performance along with the development of technology and information. Social media marketing is a marketing strategy that uses social media sites like Instagram. Social media is one of the right ways to promote products that marketers have through internet marketing which has an easy way but very extraordinary effect. Social media marketing is also an appropriate marketing tactic for marketers.

\section{Instagram Marketing}

Muttaqin (2011) states that Instagram marketing is a marketing activity carried out by using all the facilities provided by Instagram which aims to increase sales and establish better communication with consumers. The concept of Instagram marketing according to Lasmadiarta (2011) is that trust is an important thing in making an offer, through Instagram someone can build a trust by conveying messages in the form of information.

\section{RESEARCH METHODS}

This research uses descriptive qualitative research. This study emphasizes the depth of data obtained based on facts in the field (Kriyantono, 2012). Qualitative research has the main objective, to understand a social phenomenon or a phenomenon that focuses on a complete picture of a phenomenon that is studied into interrelated variables (Nissa, 2017). The research was conducted on Holyspicy's culinary business as the main source and then explained Holyspicy's integrated marketing communication strategy in the@holyspicy Instagram account as a main promotional tool to increase sales.

The subjects in this study were the first Holyspicy business owners who were used by researchers as a source to find research information, then five informants, who were followers of Holyspicy. Determination of research subjects or informants is done by purposive sampling where sampling is done deliberately in accordance with the sample requirements that have been determined by the researcher. The object in the research which is the focus of the problem to be investigated is the use of Instagram social media which is the main marketing medium in digital marketing carried out by Holyspicy.

The data collection technique is done by interview, literature study, documentation and observation. The data that has been obtained then processed with qualitative analysis (Nissa, 2017). The interview has a role when someone acts as a participant observer, even though the people at the location may not realize that the informal conversation that is being held is an interview. Then data collection techniques with literature studies, which are carried out by making books, journals and theses related and relevant to research problems that are used as a reference source as a basis and strengthen the theory in a study. Furthermore, data collection techniques with documentation, according to Hamidi, 2004: 72, documentation is information derived from important records from institutions, organizations and from individuals. documentation can be in the form of writing, pictures, or someone's work (Sugiyono 2013: 240). Then the last technique is observation, which is done thoroughly on the Instagram account Holyspicy @Holyspicy. Observation Bungin (2007: 115) defines the observation method as a method of collecting data through observation and sensing which is used to collect research data. 


\section{RESULT AND DISCUSSION}

\section{The use of Instagram as a Marketing Media}

In modern era, Instagram is one of the social media that is widely used by various business actors, both small businesses and large companies, Instagram is a social media that can help them promote products and services without the need for face-to-face promotions. Management of Instagram with good communication, promotion and marketing activities will run more effectively and efficiently. From various online food business owners, Holyspicy is one of the businesses that makes Instagram the most important marketing medium. Based on the results of an interview with Tiara Puspitasari, the owner of the Holyspicy business, stated that as a means of promotion, Instagram social media is the main marketing medium to increase sales and has a significant influence in influencing people's buying interest.

"Yes, we use Instagram, the number one is Instagram, just like Shopee Tokopedia, it's just an addition"

"For me personally, I personally know a lot from Instagram, so I thought Instagram .. a profitable selling application"

In line with the owner's opinion which stated that instagram as a means of promotion, Instagram is the main marketing medium to increase Holyspicy sales and provide a significant influence in influencing people's buying interest. All informants who are Holyspicy's followers also think that Instagram also affects their buying interest in a product. The five informants stated that uploading photos and videos by using the Instagram post feature on a regular basis can affect their buying interest and confidence in buying food online, as revealed by informant one Rani:

"Yes, I am more interested, because by looking at the pictures or videos provided by online food vendors, sometimes you can be sure to try the food."

From the five informants as followers of Holyspicy stated that uploading photos and videos through Instagram can affect their buying interest in a product, the use of Instagram as a marketing medium has provided various benefits for owners of online food businesses such as Holyspicy, by utilizing Instagram properly and utilizing it. Instagram's features that are done optimally will have a tremendous impact, especially for the future of Holyspicy and other online food business owners.

Instagram is the right new media to be used in modern technology era. Littlejohn (2009: 686) states that the internet entered a phase called web 2.0 during 2000 where everything could become more interactive and not only belong to a few but become an area for everyone. The internet, especially social media, has many features that aim to introduce brands such as sharing photos and videos uploaded on social media, so that now everyone can take a role directly and put anything on social media or the internet.

In this case, the use of Instagram as a digital communication media by Holyspicy, one of the media uses is Instagram, it used to promote Holyspicy products and brands to the public, where the promotion and introduction of Holyspicy products and brands can be done by utilizing Instagram features. Not only the post feature, Hoyspicy also takes advantage of other features such as repost which have a big impact. 
By utilizing the repost feature, Holyspicy can re-upload real testimonials provided by customers via their personal Instagram to Holyspicy Instagram. This is very helpful in Holyspicy promotional activities, especially with real testimonials given by customers, Holyspicy will also gain the trust and loyalty of consumers. As the statement expressed by the Holyspicy business owner regarding the benefits of reposts and testimonials which are also very helpful in promotional activities:

"So in the beginning, we didn't know, there was only someone who gave us a repost of testimonials, even though it was very helpful for promotion, because without knowing testimonial, customers also introduce our products to other customers, so if we look at it like Starbucks. We're always given a name right now, nowadays everyone wants a photo for a post, we are not aware his strategy is for marketing, getting free promotions from customers "

Testimonials which given by customers via Instagram, it indirectly also recommend the products they buy to other people, especially their followers or close friends. Most of the recommendations from friends will also affect the interest in buying a product. Based on the results of interviews with five informants related to the influence of recommendations from friends on their buying interest in a food product, especially during the Covid-19 pandemic, even though they did not know the details of the food production. Mostly, four of five informants, stated that recommendations from friends influenced their buying interest in a product during the Covid-19 pandemic. One of them is like the statement of informants of two Agnes regarding this matter:

"Yes, I often prioritize friends' recommendations even though I have never known how the production process because I think honest words from friends who have tried a food product make me even more interested in trying or buying it."

Then one of the five informants argued that recommendations from friends did not have much effect on their buying interest in food, especially during the Covid-19 pandemic. As revealed by informant three Jessica regarding the influence of friend recommendations on buying interest during the Covid-19 pandemic:

"Not really, even though my friends tell me that this food is delicious, but I more often master it in various social media about testimonials and packaging, how is it because it's important during the current pandemic?

From the statements of the five informants, most informants stated that recommendations from friends had an effect on their buying interest in a product during the Covid-19 pandemic, meaning that recommendations from friends, such as testimonials in the form of recommendations or reviews from friends on Instagram also had an effect on people's interest in a product .

By using social media as a marketing tool Holyspicy makes marketing activities more effective because there are no time and space constraints. Yudiana Insriastuti (2020) states that internet technology and the sophistication of cellphones are growing rapidly, making the existence of social media also develop centrally. With its sophistication and speed, everyone can connect to each other through social media. As a 
place used by humans to interact, this interaction can be carried out freely without being limited by space and time.

Holyspicy business owners are aware of the importance of marketing activities through Instagram, choosing Instagram as an online marketing medium, because of the large number of current Instagram users, especially in Indonesia. Drury (in Veby Zifania, 2014: 17) says that the use of social media has started to be used frequently in marketing. In business, social media is a means of supporting communication in marketing quickly and more profitably than selling offline. Social media is a great opportunity that can be used by business people in developing a business

In Littlejohn (2009: 413-414) regarding new media, there are two views put forward by Pierre Levy in the theory of new media. The first view is the social interaction view where Holyspicy interacts with its customers on Instagram, namely followers, either directly or indirectly. The second view is the social integration view where Holyspicy through its Instagram account indirectly creates a community, namely followers of the Holyspicy Instagram account.

\section{Pandemic Marketing}

In the midst of the Covid-19 pandemic that continues to increase, people's lives are affected. Various community activities and activities must be rescheduled until they are canceled waiting for Covid-19 to subside. One of the sectors that has been greatly affected by the existence of Covid-19 is the economic sector. Many companies have to implement Work From Home (WFH) for their employees.

Employees also receive incomplete wages due to decreased company income. Some even had to be dismissed because the company was unable to pay their employees' wages, so they had to close all company activities. This of course affects the wheels of the economy in Indonesia where there is a change in demand for goods or services which results in changes in a company's income. Entrepreneurs must think of various ways to maintain their business, one of them is through good marketing and is suitable in the midst of this pandemic situation.

Instagram, with all the conveniences and benefits it provides, can help promotional activities, especially during a pandemic that does not allow face-to-face promotions, Instagram as a means of promotion and product sales has grown quite rapidly. Nasrullah Rulli (2015: 9) states "the use of social media has developed" wildly "which at first was for socializing, becoming an arena for fighting in selling products, offering commodities, buying and selling markets, and even funnels for information on the latest events that occurred"

In this situation, marketing requires special techniques and more effort in order to achieve the desired results. As a culinary business, Holyspicy itself also faces these problems:

"Yesterday, Covid entered Indonesia, March, so March until Eid was really busy, because maybe people don't leave the house just order food by online at home. But after the opening of the PSBB there was a decrease, but in my opinion, the decrease was due to the low purchasing power of the people because during those 3 months many were sent home, right ... it means a lot of work has been lost "

This statement is also clarified with an explanation from the Holyspicy owner: 
"Um ... in my opinion, it's not a problem ... what is the problem ... people want to buy it or not, but it's a problem of purchasing power, so in my opinion now people's purchasing power is decreasing in all aspects"

As the owner of the culinary business Holyspicy, Tiara explained how the Covid19 pandemic affected his business so that his income decreased.

"Emm .. it is really high in demand in the beginning of 3 months, It could increase $100 \%$, even in the early days of the pandemic. But after PSBB there was a decrease, maybe firstly, the customer savings, people's savings decreased and secondly they also saved their money because they were at home so maybe they cook for themselves, do activities because maybe for 3 months people are still not bored, after that They are also a lot of selling, right? Bacause they are jobless so they are turning to sell"

"Erm .. in my opinion up to $20 \%$ yes"

Because of the Covid-19 pandemic, the economy has weakened and people's purchasing power has also become weak. It makes entrepreneurs also have to try harder in maintaining their income, including Holyspicy

"Yes, so during this Covid sis, we are trying to do how the income remains stable even though we work hard, it means if we only promoted it immediately got turnover, 5 million, now if to get a turnover of 5 million we have to work very hard. , so how do you increase your turnover and keep working hard for now."

The weak purchasing power of society makes entrepreneurs have to look for new ideas and innovations in their products. It is done in order to attract the interest of customers and potential consumers. In this case, Holyspicy innovates its products in order to maintain and expand the reach of its consumer market

"Um ... there's a lot, because we have to really attract customers so they buy our product. Like we have already made pudding, pudding can be eaten at all ages for children, we can continue to make lots of food menus "

In addition to have innovation, entrepreneurs are also carrying out various forms of marketing, especially in the midst of a pandemic like now in order to maintain consumers and income. As the owner of Holyspicy, Tiara adds various forms of marketing and explanations for what it does:

"Not bad, so we have 2 strategies, sorry 3 strategies, the first is advertising, the second we have a discount promotion, the third we have a giveaway. For the 10\% promo up to $25 \%$, we usually go to the shopee, but if there is a discount, the discount is sometimes if we spend 200,000 or spend 300,000 we give a discount" "There are many of our promos. We have a lot of promos at Shopee, because we see that the purchasing power has decreased so it is not like normal time, the customer is all that if I see everything is thrifty" 
"Uhm ... if the customer, uhm ... they buy a promo, for example, there are a lot of promos in grab and they buy it, on Gojek there is free shipping for them to gojek, go-food, then if at shopee there's a flash sale in shopee"

As an entrepreneur in the culinary field, Tiara explained that the existence of promos has a very big influence in increasing sales. The explanation from Tiara as the owner of Holyspicy is in accordance with what was conveyed by the informants as the buyer of Holyspicy who stated that forms of marketing such as promotions affect their buying interest. One of them is like the statement of informant one Rani as follows:

"Yes, you can say it's increased because my child likes to eat spicy food, so when Holyspicy gave me a promo, I definitely wanted to buy it because it was more economical."

The forms of marketing that a company can do on its own are very diverse. Holyspicy as an online culinary business certainly maximizes marketing through Instagram. Apart from promotions, advertisements and other activities on the Holyspicy Instagram account also affect buying interest. This was conveyed by informants, one of the third informants, Jessica:

"It is very interesting and varied in the IG, it also makes you interested in buying, besides the pictures and photos there are also some testimonials so I believe it even more"

With the many forms of marketing carried out by Holyspicy, the forms of marketing that attract consumers are also very diverse. However, based on the results of interviews with informants, he said that the forms of marketing that most interest consumers are promos and videos, as revealed by one of the informants, informant 2 Agnes.

"Promos and videos that greatly affect my buying interest"

Through the promotion held by Holyspicy in attracting consumer interest, it is a strategy in marketing communication. This promo is included in the strategy and tactics adopted by Holyspicy. Effendy (2002: 29) states that a company's marketing communication strategy is an operational tactic and serves as a map that directs the company to a goal to be achieved.

In marketing on Instagram, we often find the use of food blogger services in gaining consumer confidence in a product. However, there is a difference between Tiara's opinion as the owner of Holyspicy and buyers regarding the influence of food vloggers or food bloggers in attracting buyers, where Tiara explained that:

"Ee ... in the past, yes, in the past, for example, we are new, we endorse one blogger, yes, the followers are still below $100 \mathrm{k}$, and the addition of followers can be 1000-2000 customers, but for now even though we pay for expensive food bloggers. let's say if Farida Nurhan was already very expensive, 6 million, it didn't reach at least 300, that was difficult, but now it's possible for a food blogger, from three years ago it's booming, it's viral for now, it seems like a lot of 
people have already I don't trust food bloggers anymore, I mean he reviewed them, not being honest, so maybe it's not"

While the influence of food vloggers or food bloggers according to buyers is very diverse. By looking at the results of the interview, there are informants who still trust the opinions and suggestions of food vloggers or food bloggers. One of them is informant 4 Fitria, who still believes in food bloggers:

"I think yes because the way they promote it which uploads taste makes me want to buy the product."

However, there are also informants who in this case are also consumers of Holyspicy, who expressed their distrust of the opinions and suggestions of food vloggers or food bloggers, one of which was expressed by two informants, Agnes:

"If I'm not the type of person who follows reviews from food vloggers, yes, so it doesn't really matter if I make it trustworthy because I see food vloggers nowadays, mostly when I review they say it's always delicious"

Based on the results of the interview above, although there are buyers who do not trust the opinions and suggestions of food bloggers, more and more buyers follow and become influenced when they see food suggestions made by food bloggers so they want to try a food after seeing food blogger suggestions. It means that there are differences in thinking about the influence of food bloggers in influencing consumer buying interest, where according to Tiara as the owner of the Holyspicy business, food bloggers do not have a big influence on buying interest because they are not trusted by the community so that they do not have a significant impact on Holyspicy. However, according to buyers, the presence of a food blogger affects their buying interest because it can increase their taste for food.

There are several reasons why a company runs a business using e-commerce facilities (Morissan, 2010: 335 - 337), namely that it can reach audiences around the world, can carry out interactive communication in an efficient manner, can reach target consumers, it is easier to communicate changes. Information such as price changes and other information, improving the quality of service to customers because it is available 24 hours, seven days a week, getting immediate feedback from consumers, is an alternative distribution channel, providing cost effective and efficient dissemination of information.

In this case, Holyspicy can reach all audiences around the world at a relatively affordable cost. In addition, Holyspicy can also determine target consumers and make it easier to communicate the latest information to consumers such as the application of health protocols in the production process so that consumers can continue to know and trust Holyspicy as a culinary business that applies health protocols during the current pandemic.

\section{CONCLUSION}

The use of Instagram as a marketing and communication medium is the right step used by Holyspicy. Through Instagram, Holyspicy can provide the latest information about its products to the wider community anywhere and anytime, making Instagram an effective marketing and 
communication medium. Amid the current pandemic conditions, Holyspicy is also being affected economically by decreasing demand and income. Holyspicy itself must try harder in marketing so that it can maintain its existing market.

However, using Instagram, which is a social media that is widely used by the public during their activities at home, has a major impact on Holyspicy, where the income obtained by Holyspicy can remain stable even during this pandemic. Online marketing carried out by Holyspicy includes activities on Instagram in the form of photos, videos, giveaway, and also the existence of promos so that they can attract consumer interest. In addition, the existence of Instagram features such as hashtags, uploading photos and testimonials, and replying to comments from customers, also affects consumer buying interest. Not only that, Holyspicy also made innovations in its products in order to maintain and expand market reach.

\section{REFERENCES}

Akrimi, Y \& Khemakem, R. 2012. What Drive Customers to Spread The Word in Social Media. Journal of Marketing Research and Case Studies.

Bungin, Burhan. 2007. Penelitian Kualitatif : Komunikasi, Ekonomi, Kebijakan Publik, dan Ilmu Sosial Lainnya. Jakarta : Kencana Prenada Media Group

Creeber, G. \& Martin, R (ed.). 2009. Digital Cultures: Understanding New Media. Berkshire-England: Open University Press.

Effendy, Onong Uhcjana. 2002. Ilmu Komunikasi Teori dan Praktek. Bandung: PT. Remaja Rosdakarya

Hamidi. 2004. Metode Penelitian Kualitatif: Aplikasi Praktis Pembuatan Proposal dan Laporan Penelitian. Malang: UMM Press

Herlina, Novi. 2017. Efektivitas Komunikasi Akun Instagram @Sumbar_Rancak Sebagai Media Informasi Online Pariwisata Sumatera Barat. Universitas Riau. JOM FISIP Vol.4 No.2

Indriastuti,Y. 2020. Group Communication Relation In Social Media. Jurnal Ilmu Komunikasi, 3(1), 49-58.

Kertamukti, Rama. 2015. Strategi Dalam Periklanan. Jakarta: PT. Raka Grafindo Persada.

Kotler, Philip dan Keller. 2007. Manajemen Pemasaran. Jilid I Edisi 12. Jakarta: PT. Indeks.

Kotler, dan Keller. 2012. Manajemen Pemasaran. Edisi 12. Jakarta: Erlangga

Kriyantono, R. 2012. Teknis Praktis Riset Komunikasi. Jakarta: Kencana Prenada Media Grup.

Little john, Stephen W \& Karen A. Foss. 2009. Teori Komunikasi (theories of human communication) edisi 9. Jakarta: Salemba Humanika.

Ludwianto, Bianda. (21 Februari 2020). Riset: 64\% Penduduk Indonesia Sudah Pakai Internet.https://kumparan.com/kumparantech/riset-64-penduduk-indonesia-sudahpakai-internet-1ssUCDbKILp/full. Diakses pada 21 Agustus 2020

Machfoedz, M. 2010. Komunikasi Pemasaran Modern. Yogyakarta: Cakra Ilmu

Maribeth. 2019. Maskulinitas Dalam Akun Instagram Influencer Laki-Laki. Jurnal Ilmu Komunikasi Vol 2 No 1 (2019): Media Dan Industri Kreatif

Morissan. 2010. Periklanan: Komunikasi Pemasaran Terpadu Cetakan Pertama. Jakarta: Kencana Prenada Media Group 
Mutaqqin Z. 2011. Facebook Marketing Dalam Komunikasi Pemasaran Modern. Teknologi. Vol. 1 (No: 2) : Hal 103 - 109

Nasrullah Rulli. 2015. Media Sosial: Produser, Tren, dan Etika. Bandung: Simbiosa Rekatama Media : h.9

Nissa, F. S. (2017). Strategi Komunikasi Pemasaran Terpadu Bella Quarta. Publikasi Ilmiah Universitas Muhammdiyah Surakarta.

Rizal, Veby Zifania. 2014. Pengaruh Social Media Marketing Twitter Terhadap Terbentuknya Brand Image Restoran Burger Gaboh Pekanbaru. Universitas Riau, hal: 17.

Reza, Faisal. 2016. Strategi Promosi Penjualan Online Lazada.co.id. Jurnal Kajian Komunikasi (JKK), Vol.1, No.1, pp. 64-74. http://jurnal.unpad.ac.id

Sugiyono. 2009. Metode Penelitian Kuantitatif Kualitatif dan R\&D. Bandung: Alfabeta. 